\title{
Ovarian Brenner Tumor
}

National Cancer Institute

\section{Source}

National Cancer Institute. Ovarian Brenner Tumor. NCI Thesaurus. Code C3872.

A benign, borderline, or malignant transitional cell neoplasm arising from the ovary. It constitutes between $1 \%$ and $2 \%$ of all ovarian neoplasms. The average age at presentation is about 50 years. Grossly it is usually unilateral, firm and white or yellowish. Microscopically it consists of solid and cystic nests of epithelial cells resembling transitional epithelium surrounded by an abundant stromal component of dense, fibroblastic nature. 